Hafnes Wahyuni et al. Education on making environmentally friendly organic fertilizer to farming community in Kwala Bingai village

\title{
Education on making environmentally friendly organic fertilizer to farming community in Kwala Bingai village
}

\author{
Hafnes Wahyuni ${ }^{1 *}$, Nur Ulina Warnisyah Sebayang ${ }^{1}$, Antonio Marro Sipayung ${ }^{1}$, \\ Khairunnisa $^{2}$, Julia Syahriani Hasibuan ${ }^{2}$ \\ ${ }^{1}$ Program Studi Agroteknologi, Fakultas Pertanian, Universitas Sumatera Utara \\ ${ }^{2}$ Program Studi Manajemen Sumber Daya Perairan, Fakultas Pertanian, Universitas Sumatera \\ Utara \\ *Email: hafneswahyuni@usu.ac.id
}

\begin{abstract}
The problem of fertilizers is often a factor inhibiting agricultural development. This is due to, among other things, the relatively high price of fertilizers, limited supply, decreasing type and quality, which makes it difficult for farmers to obtain fertilizers according to their needs. An alternative to anticipating and overcoming fertilizer shortages is that farmers are encouraged to use organic fertilizers or compost. Based on these considerations, outreach activities to farmers and direct training have been carried out in August-October 2020 in Kwala Bingai Village, Stabat District, Langkat Regency, Sumatera Utara Province. The results obtained are that these activities provide many benefits to farmers such as utilizing agricultural waste for making organic fertilizers so that they are not wasted and can overcome fertilizer scarcity and high fertilizer prices by making simple organic fertilizers. and this activity should be done frequently so that agricultural waste can be utilized.
\end{abstract}

\section{Keyword: Alternative, Organic Fertilizer, Agricultural Waste}

\begin{abstract}
Abstrak
Permasalahan pupuk memang sering kali menjadi faktor penghambat pembangunan pertanian. Hal ini disebabkan antara lain harga pupuk yang relative tinggi, persediaan yang terbatas, jenis dan mutu yang semakin menurun,yang membuat petani sulit untuk mendapatkan pupuk sesuai kebutuhannya. Alternatif untuk mengantisipasi dan mengatasi kelangkaan pupuk adalah petani dianjurkan untuk menggunakan pupuk organik atau kompos. Berdasarkan pertimbangan ini maka telah dilakukan kegiatan penyuluhan kepada petani dan pelatihan langsung pada bulan Agustus-Oktober 2020 di Kelurahan Kwala Bingai Kecamatan Stabat Kabupaten Langkat Provinsi Sumatera Utara. Hasil yang didapatkan adalah kegiatan tersebut banyak memberikan manfaat kepada para petani seperti pemanfaatkan limbah pertanian untuk pembuatan pupuk organic sehingga tidak terbuang sia-sia dan dapat mengatasi kelangkaan pupuk serta harga pupuk tinggi dengan membuat pupuk organic sederhana. dan sebaiknya kegiatan ini sering dilakukan supaya limbah pertanian bisa dimanfaatkan.
\end{abstract}

\section{Kata Kunci: Alternatif, Pupuk Organik, Limbah Pertanian}

\section{PENDAHULUAN}

Kwala Bingai merupakan salah satu kelurahan yang ada di kecamatan Stabat, Kabupaten Langkat, provinsi Sumatra Utara, Indonesia. Mata pencaharian masyarakat mayoritas bertani dengan menanam tanaman pangan seperti padi, jagung dan kedelai, sebagian kecil ada yang menanam sayursayuran.

Masyarakat tani di kelurahan Kwala Bingai menerapkan budidaya secara konvensional dengan menggunakan pupuk kimia sintesis secara terus-menerus. Umumnya, petani di Indonesia sebagian 
Hafnes Wahyuni et al. Education on making environmentally friendly organic fertilizer to farming community in Kwala Bingai village

besar masih mengunakan cara bercocok tanam secara konvensional. Dalam penggunaan pupuk juga para petani hanya menggunakan pupuk buatan NPK saja (Haerul et al., 2015). Dampak penggunaan pupuk kimia sintesis dalam jangka panjang dapat berpengaruh buruk terhadap lingkungan. Menurut (Herdianto,2015) pemakaian pupuk anorganik dalam jumlah berlebihan dapat merusak kualitas tanah.

Permasalahan pupuk memang sering kali menjadi faktor penghambat pembangunan pertanian. Hal ini disebabkan antara lain harga pupuk yang relative tinggi, persediaan yang terbatas, jenis dan mutu yang semakin menurun,yang membuat petani sulit untuk mendapatkan pupuk sesuai kebutuhannya. Masalah yang sering dihadapi oleh semua petani di Indonesia adalah masalah kelangkaan pupuk yang menjadi kendala utama dalam peningkatan produksi. Sementara pupuk bersubsidi yang diharapkan bisa meringankan petani, justru hilang dari pasaran

Salah satu alternatif untuk mengantisipasi dan mengatasi kelangkaan pupuk adalah petani dianjurkan untuk menggunakan pupuk organik atau kompos. Pemberian bahan oranik dapat memperbaiki sifat kimia tanah (Afandi, 2015). Oleh karena itu penting untuk aplikasi pupuk organik secara berkelanjutan mengingat bahan utama pembuatan pupuk organic tersebut adalah limbah pertanian dan peternakan.

Melihat potensi yang ada pada kelompok tani Karya Tani II di Kelurahan Kwala Bingai penerapan ipteks untuk edukasi pembuatan pupuk organic yang ramah lingkungan dan pelatihan pembuatan pupuk organic perlu disosialisasikan untuk mengatasi permasalahan-permasalahan tersebut.

Tujuan dari kegiatan ini adalah untuk meningkatkan pengetahuan para petani di Kelurahan Kwala Bingai dalam hal pembuatan pupuk organik yang ramah lingkungan melalui penyuluhan dan sosialisasi dan untuk mengajak para petani untuk membuat pupuk organic untuk pemakaian sendiri sehingga bisa mengatasi kelangkaan pupuk buatan jika tidak tersedia pada saat dibutuhkan. Kemudian untuk meningkatkan keterampilan serta mengajak para peteni untuk membuat pupuk organic dengan metode yang sederhana sehingga dapat dilakukan secara mandiri.

\section{METODE PELAKSANAAN}

Kegiatan ini telah dilakukan pada bulan Agustus sampai Oktober 2020 di Kelurahan Kwala Bingai Kecamatan Stabat Kabupaten Langkat Provinsi Sumatera Utara dengan melibatkan kelompok tani. Alat yang digunakan dalam kegiatan ini adalah camgkul, kayu, gembor, pengukur suhu tanah, alat tulis dan kamera. Bahan yang digunakan yaitu kotoran sapi, jerami padi, EM4 dan terpal. Kegiatan ini meliputi 2 tahap yaitu tahap pertama penyuluhan dengan cara memberikan materi tentang pembuatan pupuk organic kepada para petani menggunakan standing bener lalu di presentasikan. Kemudian dilakukan sesi tanya jawab antara pemateri dengan kelompok tani.

Tahap yang kedua yaitu praktek langsung yang dilakukan oleh para petani dengan cara para petani langsung praktek di lapang untuk membuat pupuk organik dengan menggunakan bahan-bahan yang telah disediakan.

\section{HASIL DAN PEMBAHASAN}

Berdasarkan kegiatan Pengabdian Kepada Masyarakat yang telah dilaksanakan pada bulan Oktober 2020 bersama dengan kelompok tani Karya Tani II di Kelurahan Kwala Bingai Kecamatan Stabat Kabupaten Langkat Provinsi Sumatera Utara yaitu dengan kegiatan pertama kunjungan oleh tim pengabdian pada bulan September 2020 dengan membahas rencana kegiatan yang dilakukan yaitu penyuluhan dengan cara memberikan materi tentang pembuatan pupuk organic sederhana dengan memanfaatkan sisa panen berupa jerami padi dan kotoran ternak sapi dengan cara memberikan presentasi langsung. Kegiatan yang dilakukan dengan petani sudah menjalankan protocol Kesehatan untuk menghindari penyebaran virus Covid-19. Kemudian kegiatan kedua yaitu praktek langsung yang dilakukan oleh para petani di lapang. 
Hafnes Wahyuni et al. Education on making environmentally friendly organic fertilizer to farming community in Kwala Bingai village

\subsection{Kegiatan Penyuluhan}

Kegiatan penyuluhan kepada petani ini bertujuan untuk memberikan ilmu pengetahuan, manfaat penggunaan pupuk organic dan cara pembuatan pupuk organic sederhana dengan memanfaatkan limbah pertanian seperti jerami padi hasil sisa panen yang diketahui masih mengandung unsur hara dan dapat memperbaiki sifat kimia tanah. Pane (2014) menyatakan bahwa kompos jerami padi dapat meningkatkan C-organik dan P-tersedia tanah Ultisol serta serapan $\mathrm{N}$ dan serapan P. Kemudian kotoran ternak dapat juga dimanfaatkan sebagai bahan utama pembuatan pupuk organic karena dapat memperbaiki sifat fisik dan kimia tanah.

Kegiatan penyuluhan yang dilakukan oleh tim Pengabdian Kepada Masyarakat dihadiri oleh Ketua dan Wakil Ketua serta anggota kelompok tani Karya Tani II di Kelurahan Kwala Bingai Kecamatan Stabat Kabupaten Langkat Provinsi Sumatera Utara. Kegiatan dibuka oleh Ketua kelompok tani dan Ketua tim Pengabdian Kepada Masyarakat dan dilanjutkan oleh tim Pengabdian Kepada Masyarakat.
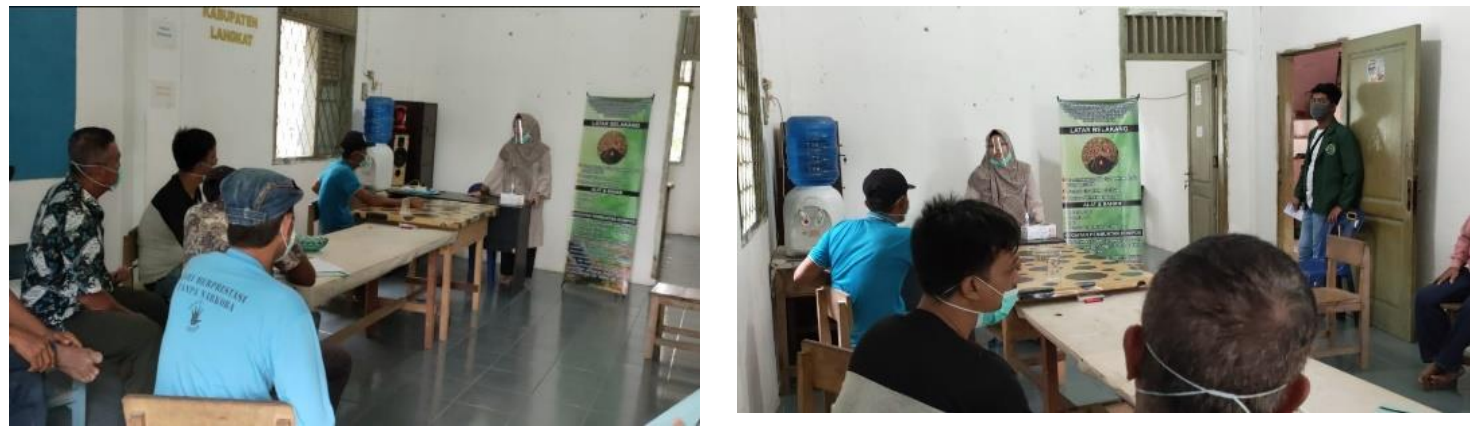

Gambar 3.1. Kegiatan penyuluhan oleh Tim Pengabdian Kepada Masyarakat

\subsection{Pelatihan Pembuatan Pupuk Organik}

Pada kegiatan tahap kedua dilakukan pelatihan dengan cara praktek langsung pembuatan pupuk organic sederhana oleh para petani yang dipandu langsung oleh Tim Pengabdian Kepada Masyarakat dengan menggunakan bahan dan alat yang telah disediakan oleh tim pengabdian kepada masyarakat. Tim pengabdian kepada masyarakat membimbing para petani untuk membuat pupuk organic dengan metode yang sederhana dan tidak memnutuhkan biaya yang mahal. Berdasrkan pelatihan yang sudah dilakukan diharapkan dapat memberikan pengetahuan kepada para petani untuk membuat pupuk organic sederhana sehingga limbah pertanian tidak terbuang sia-sia dan para petani juga terbantu untuk mendapatkan tambahan pupuk untuk tanaman budidayanya serta ramah lingkungan.
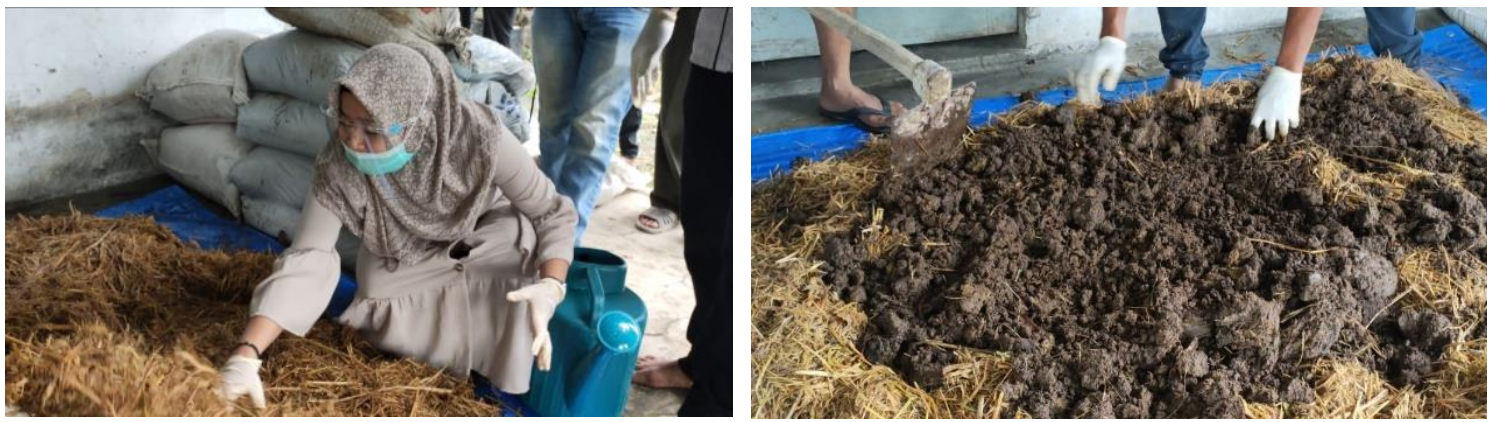
Hafnes Wahyuni et al. Education on making environmentally friendly organic fertilizer to farming community in Kwala Bingai village
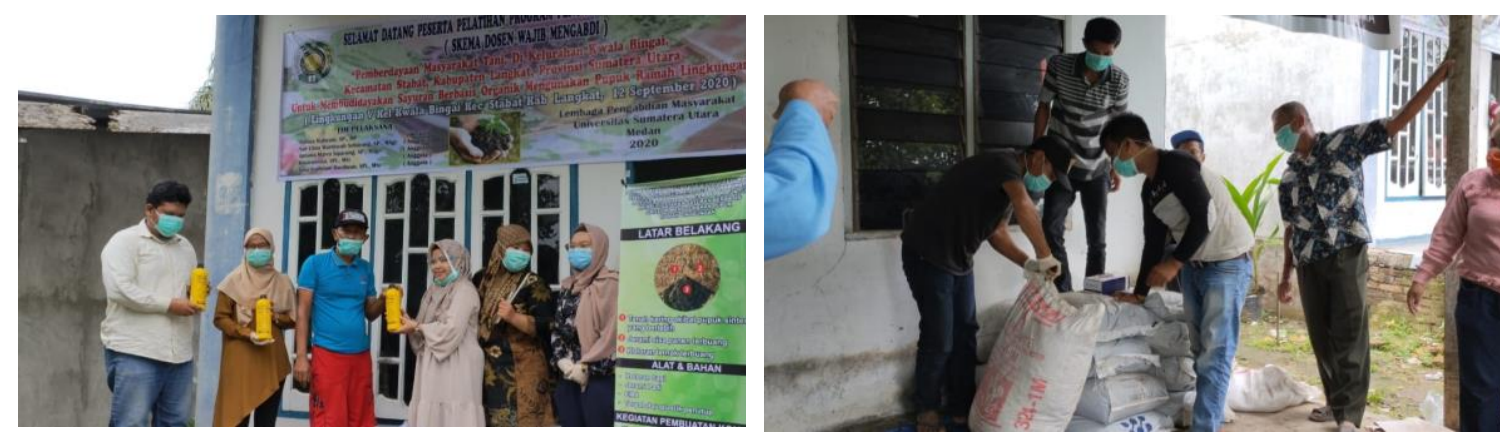

Gambar 3.2. Kegiatan pelatihan bersama para petani

\section{KESIMPULAN}

Berdasarkan seluruh kegiatan Pengabdian Kepada Masyarakat yang telah dilakukan dapat disimpulkan bahwa kegiatan tersebut banyak memberikan manfaat kepada para petani seperti pemanfaatkan limbah pertanian untuk pembuatan pupuk organic sehingga tidak terbuang sia-sia dan dapat mengatasi kelangkaan pupuk serta harga pupuk tinggi dengan membuat pupuk organic sederhana. Pada kegiatan tahap pertama yaitu penyuluhan kepada petani dapat dilihat dengan antusias para petani Karya Tani II di Kelurahan Kwala Bingai Kecamatan Stabat Kabupaten Langkat Provinsi Sumatera Utara secara langsung sudah membuka wawasan dan menambah pengetahuan para petani tentang pupuk organic. Selanjutnya pada kegiatan kedua dapat disimpulkan bahwa para petani mulai paham cara pembuatan pupuk organic sederhana melalui praktek langsung dan sebaiknya kegiatan ini sering dilakukan supaya limbah pertanian tidak terbuang sia-sia.

\section{UCAPAN TERIMAKASIH}

Terimakasih kepada Rektor USU dan LPPM USU yang telah memberikan dana pengabdian tahun 2020 Skema Dosen Wajib Mengabdi pada Program Pengabdian Kepada Masyarakat yang Dibiayai oleh dana NON PNBP Universitas Sumatera Utara dengan nomor 695/UN5.2.3.2.1/PPM/2020. Terimakasih juga kepada kelompok tani Karya Tani II di Kelurahan Kwala Bingai Kecamatan Stabat Kabupaten Langkat Provinsi Sumatera Utara sebagai mitra dalam Pengabdia Kepada Masyarakat ini.

\section{DAFTAR PUSTAKA}

Afandi N A, Siswanto B, Nuraini Y 2015 Pengaruh pemberian berbagai jenis bahan organik berpengaruh terhadap pertumbuhan dan produksi tanaman Jurnal Tanah dan Sumber Daya Lahan.2 (2) pp 237-244

Haerul, Muammar, dan Isnaini J L 2015 Pertumbuhan dan produksi tanaman tomat (Solanum lycopersicum L.) terhadap POC (Pupuk Organik Cair) J. Agrotan 1 (2) pp 69-80

Herdianto D dan Setiawan A 2015 Upaya peningkatan kualitas tanah melalui sosialisasi pupuk hayati, pupuk organik, dan olah tanah konservasi Jurnal Aplikasi Ipteks Untuk Masyarakat 4 (1) pp 47-53

Pane M A, Damanik M M B, Sitorus B 2014 Pemberian bahan organic kompos jerami padi dan abu sekam padi dalam memperbaiki sifat kimia tanah Ultisol serta pertumbuhan tanaman jagung Jurnal Online Agroekoteknologi 2 (4) pp 1426-1432 